\title{
CORRIGENDUM
}

\section{Diet restriction and ageing in the dog: major observations over two decades}

D. F. Lawler, B. T. Larson, J. M. Ballam, G. K. Smith, D. N. Biery, R. H. Evans, E. H. Greeley, M. Segre, H. D. Stowe and R. D. Kealy

(First published online 7 August 2008)

doi:10.1017/S0007114507871686, Published by Cambridge

University Press, 06 December 2007.

In error, Fig. 6 (a) was incorrectly reproduced instead of Fig. 6 (b) in the above publication. Figure 6 (b) as it should have appeared is printed below ${ }^{(1)}$.

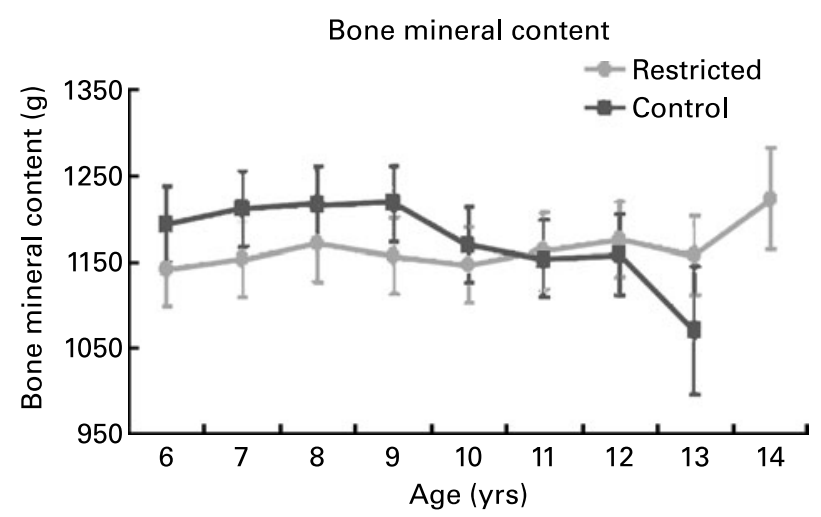

\section{Reference}

1. Lawler DF, Larson BT, Ballam JM, Smith GK, Biery DN, Evans RH, Greeley EH, Segre M, Stowe HD \& Kealy RD (2008) Diet restriction and ageing in the dog: major observations over two decades. Br J Nutr 99, 793-805, Published by Cambridge University Press, 06 December 2007, doi:10.1017/S0007114507871686. 